\title{
AML mRNA Positive Lysate Loaded Autologous Dendritic Cell Vaccine
}

National Cancer Institute

\section{Source}

National Cancer Institute. AML MRNA Positive Lysate Loaded Autologous Dendritic Cell

Vaccine. NCI Thesaurus. Code C74000.

A cancer vaccine consisting of autologous dendritic cells loaded with separate preparations of acute myelogenous leukemia (AML) cell lysate and AML-specific messenger RNA (mRNA) with potential immunostimulatory and antineoplastic activities. Upon administration, AML mRNA plus lysate loaded autologous dendritic cell vaccine may elicit a potent cytotoxic $\mathrm{T}$-cell $(\mathrm{CT} \mathrm{L})$ response against $\mathrm{AML}$ cells, resulting in tumor cell death. Autologous dendritic cells doubly-loaded with AML cell lysate and AML-specific mRNA may elicit superior primary, recall, and effector lytic immune responses compared to autologous dendritic cells loaded with tumor lysate or tumor mRNA alone. 